\title{
Uveitis sarcoidosisban
}

\author{
Szepessy Zsuzsanna dr. \\ Semmelweis Egyetem, Általános Orvostudományi Kar, Szemészeti Klinika, Budapest
}

\begin{abstract}
A szerző a sarcoidosis uveitises tüneteit és a differenciáldiagnózis nehézségeit egy eset kapcsán ismerteti. Az 57 éves nőbeteg mindkét szemének látásromlása miatt került a Szemészeti Klinikára (visus od: 0,5; os: 0,1). Mindkét oldali cornea hátlapján precipitátumokat találtak, az elülső csarnok tyndallisatiójával, hátsó synechiákkal és az üvegtest beszűrtségével. Bal oldali fundusán multifokális, elmosódott szélű chorioretinitises gócokat észleltek. Általános kivizsgálása során mellkas-röntgenfelvételén mindkét oldalon disszemináltan gombostűfejnyi gócárnyékokat találtak, ami felvetette tuberculosis lehetőségét. A laboratóriumi vizsgálatok nem erősítették meg egyértelmúen a tuberculosist; a bronchoszkópos tüdőbiopszia sarcoidosist diagnosztizált. A beteg szisztémás kortikoszteroidterápiában részesült, amelyre visusa jelentősen javult (od: 0,9 ; os: 0,5 ). A szerző felhívja a figyelmet arra, hogy a sarcoidosis változatos uveitises tünetekkel járhat. Differenciáldiagnosztikai szempontból a tuberculosistól való elkülönítése sok esetben csak hisztopatológiailag lehetséges, ami a terápia megválasztása szempontjából döntő fontosságú.

Orv. Hetil., 2013, 154(45), 1798-1801.
\end{abstract}

Kulcsszavak: sarcoidosis, uveitis, tuberculosis

\section{Uveitis in sarcoidosis}

This case report demonstrates signs of uveitis and difficulties of the differential diagnosis of sarcoidosis as the cause of uveitis. A 57-year-old woman, who had visual loss in her both eyes, developed bilateral panuveitis: bilateral precipitates on the cornea with posterior synechia and infiltrates in the vitreous, and multifocal, peripheral retinochoroiditis. Chest X-ray revealed an infiltrate and numerous smaller granulomas in both lungs. The presumptive diagnosis was tuberculosis, however, biopsy of the pulmonal lesion showed sarcoidosis. Pulmonary and ophthalmologic findings rapidly disappeared with corticosteroid therapy. The author concludes that sarcoidosis may present with different signs of uveitis. Histopathology is of great importance for the differentiation between sarcoidosis and tuberculosis, which is very important for the therapy.

Keywords: sarcoidosis, uveitis, tuberculosis

Szepessy, Zs. (2013). [Uveitis in sarcoidosis]. Orv. Hetil., 154(45), 1798-1801.

(Beérkezett: 2013. augusztus 25.; elfogadva: 2013. szeptember 23.)

A szerkesztőség felkérésére készült közlemény.

A sarcoidosis (morbus Boeck) krónikus, granulomatosus, több szervet érintő, autoimmun megbetegedés. Leggyakrabban a tüdő, a mediastinalis nyirokcsomók, a bơr és a szem érintettségével jelentkezik. Ritkábban idegrendszeri [1], máj-, lép- [2] és szív- [3] eltéréseket is okozhat. Etiológiája ismeretlen, 20 és 40 éves életkor között a leggyakoribb, de bármely életkorban kialakulhat. A sarcoidosis prevalenciája világszerte eltérést mutat. Európában észak-dél irányban csökken az előfordulása [2].

Szemészeti manifesztáció az esetek 30-70\%-ában van jelen, ami a betegség első tünete is lehet [4]. A változa- tos tünetek érinthetik az orbita szöveteit, különösen a könnymirigyet, a szemhéj bőrét, a szemfelszínt: leggyakrabban száraz szem és conjunctivalis granuloma formájában. Sok esetben intraocularis gyulladásként, uveitisként jelentkezik, amely lehet elülső, intermedier és hátsó uveitis is. Tuberculosisendémiás területeken, például Indiában a sarcoidosis legismertebb és leggyakoribb jellemzője az uvea minden rétegének gyulladása: a panuveitis. Európában ritkább ez a megjelenési forma [4].

Differenciáldiagnosztikai szempontból a tuberculosistól való elkülönítése okoz nehézséget, hiszen a két betegség klinikai és radiológiai tünetei hasonlóak [5]. 


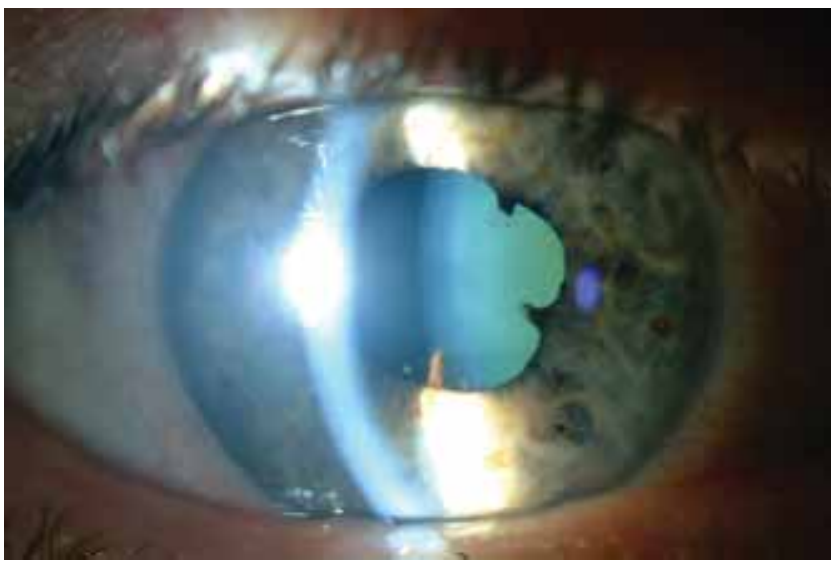

1. ábra

Résfotó a bal szem elülső szegmentumáról. Precipitátumok a cornea hátlapján. Hátsó synechiák: az iris több helyen lenőtt a lencséhez

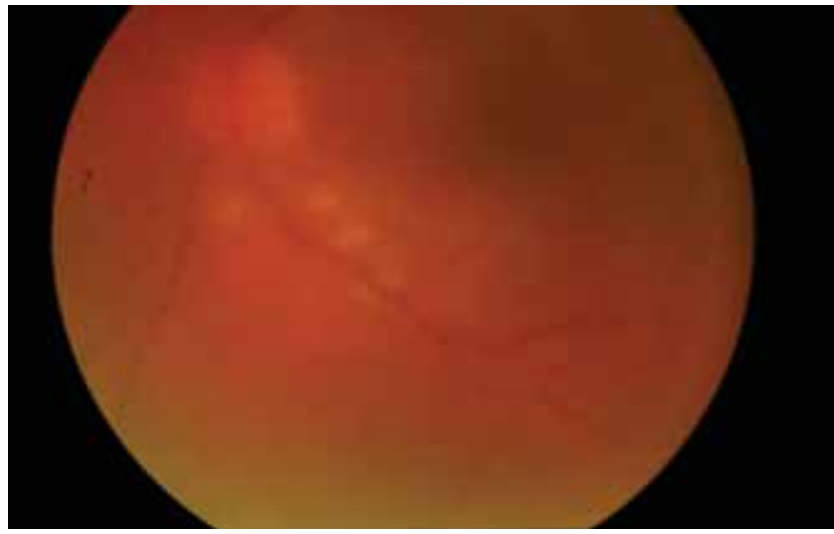

2. ábra

Fundusfotó a bal szem hátsó szegmentumáról. Az üvegtes beszúrt; a papilla alatt az alsó temporalis érárkád mellett multifokális, elmosódott szélú chorioretinitises gócok láthatóak

Így sok esetben csak szövettani mintavétel után állítható fel a helyes diagnózis. Hisztopatológiailag elkülöníthetőek, mert sarcoidosisban az epitheloid sejtekből álló sejtfészkek (granuloma) elsajtosodást nem mutatnak; míg tuberculosis esetén a granulomákban elsajtosodás figyelhető meg [6].

\section{Esetismertetés}

Az 57 éves nőbetegünk mindkét szemének látásromlása miatt került intézetünkbe. A sovány, hypertoniás beteg belgyógyászati anamnéziséből kiemelendő a hónapok óta fennálló hátfájdalom, ízületi fájdalom, három hónap alatt bekövetkezett jelentős mértékű (mintegy $20 \mathrm{~kg}$ ) fogyás. Köhögésre és dyspnoéra nem panaszkodott, lázas megbetegedése az utóbbi időben nem volt. Korábban mindkét szemével egyformán jól látott, szemsérülés nem érte, szemmütéte nem volt.

Szemészeti vizsgálatakor a jobb szem távoli visusa korrekcióval (+3.0 Dsph): 0,5; bal szem távoli visusa korrekcióval (+3.0 Dsph): 0,1 volt. Szemnyomása mindkét oldalon a normális tartományban volt. Réslámpás vizs-
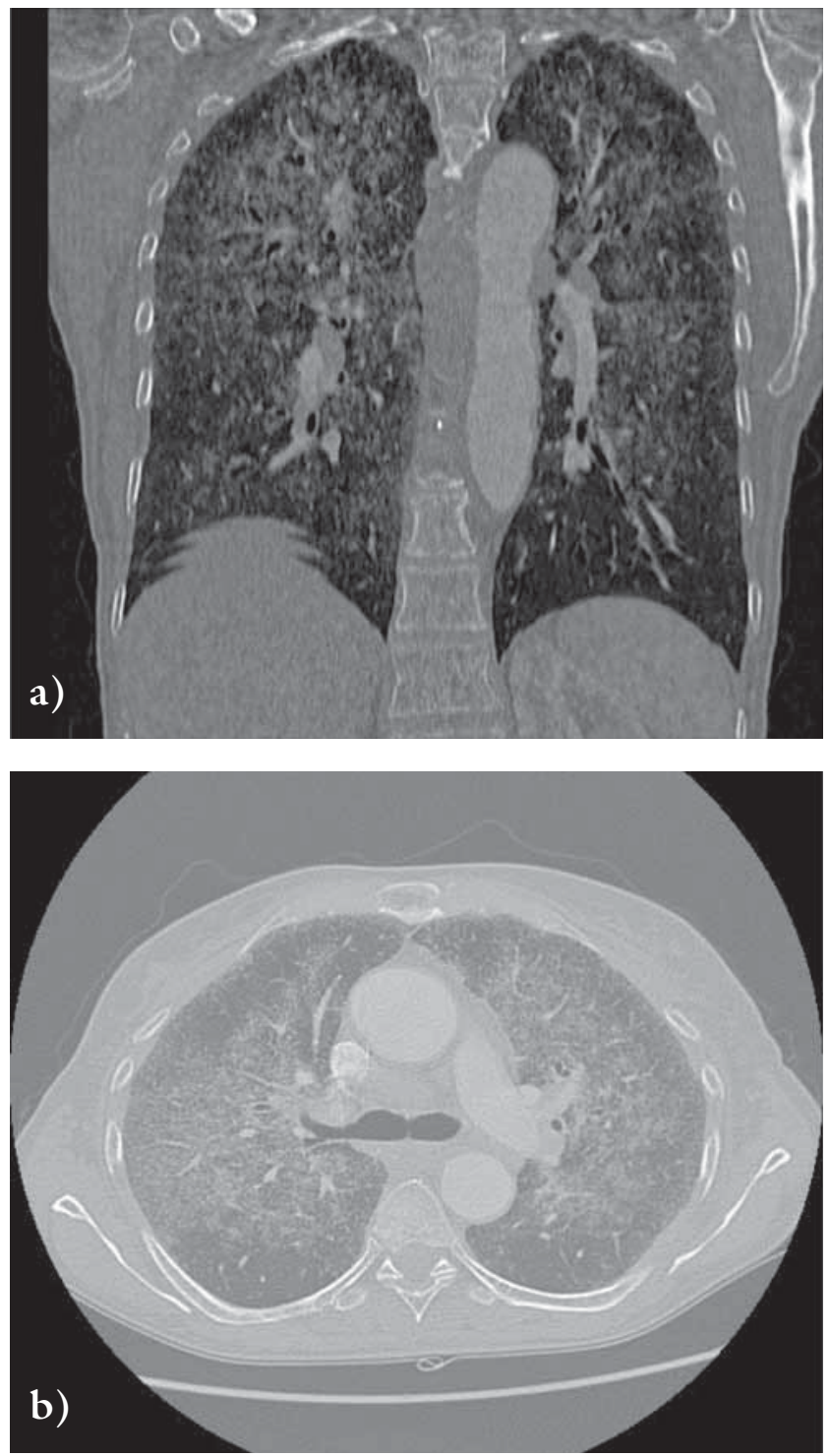

3. a)-b) ábra $\quad$ Mellkas-CT-felvétel: Mindkét tüdőben apró miliaris jellegú rajzolatfokozódás. A mediastinumban és a hilusokban patológiás, megnagyobbodott nyirokcsomók

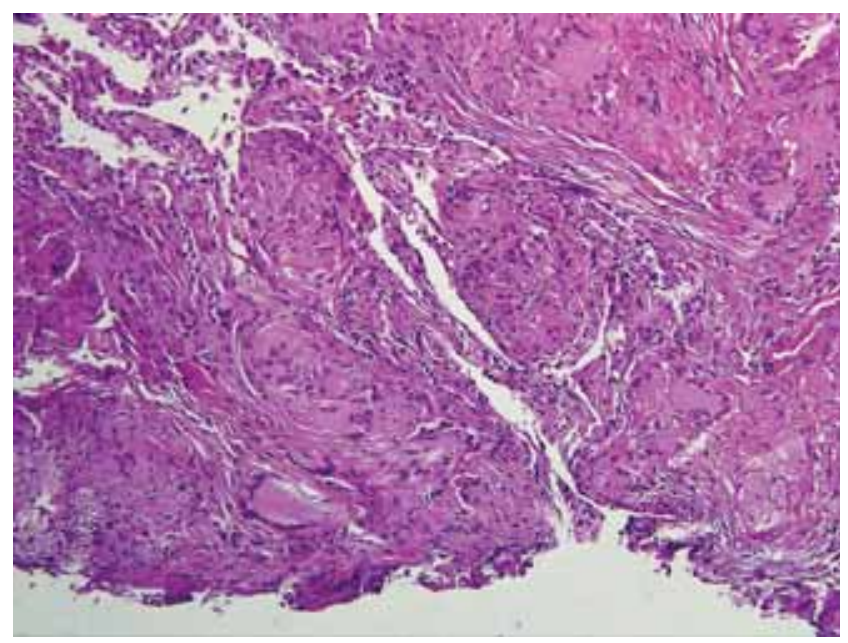

\begin{tabular}{l|l} 
4. ábra & Sarcoidosisra jellegzetes epitheloid sejtes granulomák tüdőbiop-
\end{tabular} sziás mintában (hematoxilin-eozin festés, közepes nagyítás) 
gálat során mindkét oldalon ciliaris belövelltséget, a cornea hátlapján apró, finom precipitátumokat találtunk az elülső csarnok tyndallisatiójával. Jobb oldalon VI h-nál, bal oldalon I h, IV h és VI h-nál hátsó synechiát láttunk (1. ábra). Biomikroszkópos (superfield Volk-lencse) szemtükrözés során mindkét oldali üvegtestben sejtek voltak; az üvegtest beszűrt volt. Bal oldali fundusán, a papilla alatt az alsó temporalis érárkád mellett multifokális, elmosódott szélú chorioretinitises gócokat diagnosztizáltunk (2. ábra).

Általános kivizsgálása során rutinlaborleletéből kiemelendő a kissé emelkedett májenzimérték (gammaglutamiltranszferáz $35 \mathrm{U} / 1$, normális $30 \mathrm{U} / 1$ alatt). A szerológiai vizsgálatok akut fertőzést nem igazoltak. Immunológiai laboratóriumi vizsgálatok kromatin elleni antitest-pozitivitást, illetve antinukleáris antitest 1:40 és 1:160 hígításban is gyengén pozitivitást jelzett.

Korábbi mellkas-röntgenfelvételén mindkét oldalon vaskosabb hilusokat, mindkét tüdőben disszemináltan gombostüfejnyi gócárnyékokat, a bázison kiterjedt fibroticus rajzolatfokozódást találtak. A vaskos hilusok és a rajzolatfokozódás alapján interstitialis tüdőbetegség volt feltételezhető, de a disszeminált gócárnyékok felvetették tuberculosis lehetőségét. Pulmonológiai kivizsgálása során speciális laboratóriumi vizsgálatok történtek annak eldöntésére, hogy sarcoidosis vagy tuberculosis a diagnózis. Az első tünetként diagnosztizált kétoldali panuveitis mindkét betegségnek megfelelt, hiszen mindkettő jelentkezhet ebben a formában. A tüdőgyógyászati speciális vizsgálatok közül a QuantiFERON-TB Gold teszt pozitív lett, ami a tuberculosist támasztotta alá. A köpettenyészetből azonban Mycobacterium nem tenyészett ki, és a direkt kenetben sem találtak saválló pálcát. Az angiotenzinkonvertáló enzim (sACE: 208 U/1) emelkedett értéket mutatott, ami sarcoidosisra jellemző, de a szérumkalcium $(2,37 \mathrm{mmol} / \mathrm{l})$ a normális tartományban volt, ami sarcoidosisban ugyancsak emelkedett lehet. A laboratóriumi vizsgálatok nem erôsítették meg egyértelmúen sem a tuberculosist, sem a sarcoidosist. Ekkor mellkas-CT-vizsgálat történt, ami bilateralis hilaris lymphadenopathiát, valamint mindkét tüdőben apró miliaris jellegú rajzolatfokozódást írt le [3.a) és b) ábra]. Ez a vizsgálat az interstitialis tüdőbetegség, sarcoidosis diagnózisát támasztotta alá. Az egyértelmű választ a bronchoszkópos tüdőbiopszia nyújtotta, ami minden kétes esetben elvégzendő. A diagnózis a terápia megválasztása szempontjából döntő fontosságú, hiszen ezen múlik, hogy antituberkulotikus kezelésben vagy kortikoszteroidterápiában részesül a beteg. Esetünkben szövettanilag nem elsajtosodó granulomákat, epitheloid sejtekból álló sejtfészkeket írtak le (4. ábra), vagyis sarcoidosist diagnosztizáltak.

Betegünk tüdőgyógyászaton szisztémás kortikoszteroidterápiában részesült, aminek hatására az intraocularis gyulladás tünetei is megszűntek. A látóélesség három hónap elteltével jelentősen javult: a jobb szemen a visus: 0,9 ; a bal szemen a visus: 0,5 .

\section{Megbeszélés}

A sarcoidosis diagnózisának felállításában a klinikai megjelenés, a képalkotó vizsgálatok, a laboratóriumi tesztek és a szövettan nyújt segítséget.

Intraocularis sarcoidosis eseteiben az intraocularis tünetek a diagnosztika első pillérének tekinthetőek. Egy nemzetközi munkacsoport (International Workshop On Ocular Sarcoidosis) [7] 2009-ben a következőkben foglalta össze az intraocularis sarcoidosis jeleit:

1. Szaruhártya-precipitátumok és/vagy iriscsomók (Koeppe vagy Busacca).

2. Trabecularis hálózat nodulusai és/vagy perifériás elülső synechiák.

3. Üvegtest gyulladása: vitritis és/vagy „hógolyó”, „hópad” a periférián.

4. Multifokális chorioretinitis.

5. Retinalis vasculitis, periphlebitis.

6. Papillagranuloma és/vagy chorioideagranuloma.

7. Bilateralis megjelenés.

Ha a felsorolt tünetek közül négy jelen van, akkor intraocularis sarcoidosis diagnózisa feltételezhető. Ekkor következik a diagnosztika második pillére: a laboratóriumi tesztek, képalkotó diagnosztika, amelyekkel meg kell erősíteni a feltételezett diagnózist. A nemzetközi munkacsoport kimondta, hogy ha a következő négy laboratóriumi tesztvizsgálat közül kettő teljesül az intraocularis tünetek mellett, akkor a sarcoidosis diagnózisa felállítható:

1. Negatív tuberkulinteszt.

2. Emelkedett szérum angiotenzinkonvertáló enzim (ACE) és/vagy emelkedett szérumlizozim.

3. Mellkasröntgen/mellkas-CT: bilateralis hilaris lymphadenopathia.

4. Kóros májenzimértékek [7].

Hangsúlyoznunk kell, hogy a sarcoidosis kizárásos diagnózis. Ha differenciáldiagnosztikai nehézséget tapasztalunk, ellentmondásosak az eredmények (mint ismertetett esetünkben), akkor következik a diagnosztika harmadik pillére, a szövettani mintavétel az érintett területről. Hisztopatológiailag epitheloid sejtekből álló, keskeny lymphocytaszegéllyel övezett sejtfészkek, ritkán Langhans-típusú óriássejtek és az el nem sajtosodó granulomák adják a sarcoidosis szövettani diagnózisát [6].

Esetünk fó kérdését, nehézségét a sarcoidosis vagy tuberculosis dilemmája adta. A két megbetegedés intraocularis megjelenési formái hasonlóak, granulomatosus uveitisként, panuveitisként jelentkezhetnek. Szemészeti szempontból csak az intraocularis tünetek alapján nem különíthetőek el egymástól. Szükségesek a laboratóriumi és képalkotó vizsgálatok.

Betegünknél a tuberculosis lehetôségére a mellkasröntgen és a QuantiFERON-TB Gold teszt pozitivitása hívta fel a figyelmet. Az utóbbi időben az interferongamma release assay (IGRA) tesztek közül a Quanti- 
FERON-TB Goldot a manifeszt és latens Mycobacterium tuberculosis-fertőzés kimutatására használják hazánkban, amelynek szenzitivitása és specificitása jobb a tuberkulin bőrteszthez (Mantoux-próba) viszonyítva, és immunszupprimáltaknál is alkalmazható. A tisztítottfehérje-derivátumot intradermalisan alkalmazó tuberkulin bőrpróba késői típusú (IV.) sejt mediálta reakcióval mutatja ki a fertőzést, míg az in vitro alkalmazott interferon-gamma-teszt a perifériás vérben található antigén-specifikus immunreakciót detektálja [8]. Sarcoidosisban azonban a QuantiFERON vizsgálat álpozitivitást mutathat, ami esetünkben is jelentkezett.

Tuberculosisendémiás területeken a tuberkulin bőrteszt elvégzését is javasolják, ami közel 90\%-ban anergiát mutat sarcoidosisban. Immunszupprimáltakon azonban csak az interferon-gamma release assay (IGRA) tesztek eredményét fogadják el [9].

Esetünkben sarcoidosist feltételezhettünk a négy meglévő szemészeti tünetből: precipitátumok a cornea hátlapján, vitritis, multifokális chorioretinitis és bilateralis megjelenés. A jól ismert szérum angiotenzinkonvertáló enzim emelkedése is erre utalt, bár ez csak a betegek felében mutatkozik az irodalmi adatok alapján, és tuberculosisban is megfigyelhető $[4,5]$. A szérumkalciumszint viszont az esetek 30\%-ában emelkedett lehet [4, 5], de betegünknél a normális tartományban volt. Mellkas-CT-felvételekkel azonban az interstitialis tüdőbetegség és lymphadenopathia már valószínüsíthető volt. Szövettani vizsgálattal pedig bizonyítást nyert a sarcoidosis.

Ocularis sarcoidosisban bilateralis, hátulsó szegmentum érintettsége esetén szisztémás kortikoszteroidterápia indítandó. Azoknál a betegeknél, akik kortikoszteroidra nem megfelelően reagálnak vagy súlyos mellékhatások jelentkeznek, immunszuppresszió alkalmazandó [10]. $\mathrm{Az}$ irodalomban sikeres TNF-alfa-gátló kezelésról is (infliximab, adalimumab) beszámoltak intolerábilis immunszuppresszió után [11].

A sarcoidosis prognózisa szemészeti érintettségben jó, ha időben felismerésre kerül [12]. A legnagyobb differenciáldiagnosztikai problémát a tuberculosis jelenti, ami a terápia megválasztása szempontjából döntő fontosságú. A szemészeknek ehhez szorosan együtt kell müködniük a belgyógyászokkal, pulmonológusokkal, radiológusokkal, hiszen a sarcoidosis valódi multiszisztémás megbetegedés.

\section{Köszönetnyilvánítás}

A szerző köszönetét fejezi ki $d r$. Fillinger János osztályvezető főorvos úrnak (Országos Korányi Tbc- és Pulmonológiai Intézet, Patológia Osztály), aki a szövettani felvételt rendelkezésre bocsátotta.

\section{Irodalom}

[1] Segal, B. M.: Neurosarcoidosis: diagnostic approaches and therapeutic strategies. Curr. Opin. Neurol., 2013, 26, 307-313.

[2] Tóth, M., Weninger, Cs., Moró, Zs., et al.: Sarcoidosis involving liver and spleen and with hypercalcemia. [Sarcoidosis máj- és lépérintettséggel, hypercalcaemiával.] Magyar Radiológia, 2007, 81, 272-275. [Hungarian]

[3] Berkenboom, G., Hulet, F., Remmelink, M., et al.: Severe myocardial fibrosis in a patient with cardiac sarcoidosis. Acta Cardiol., 2013, 68, 231-232.

[4] Babu, K.: Sarcoidosis in tuberculosis-endemic regions: India. J. Ophthalmic Inflamm. Infect., 2013, 3, 53

[5] Ongchin, S., Keene, C. D., Van Gelder, R., et al.: A diagnostic dilemma: infectious versus noninfectious multifocal choroiditis with panuveitis. J. Ophthalmic Inflamm. Infect., 2013, 3, 26.

[6] Mitchell, D. N., Scadding, J. G., Heard, B. E., et al.: Sarcoidosis: histopathological definition and clinical diagnosis. J. Clin. Pathol., 1977, 30, 395-408.

[7] Herbort, C. P., Rao, N. A., Mochizuki, M.: International criteria for the diagnosis of ocular sarcoidosis: results of the first International Workshop On Ocular Sarcoidosis (IWOS). Ocul. Immunol. Inflamm., 2009, 17, 160-169.

[8] Albini, T. A., Karakousis, P. C., Rao, N. A.: Interferon-gamma release assays in the diagnosis of tuberculous uveitis. Am. J. Ophthalmol., 2008, 146, 486-488.

[9] Gupta, D., Kumar, S., Aggarwal, A. N., et al.: Interferon gamma release assay (QuantiFERON-TB Gold In Tube) in patients of sarcoidosis from a population with high prevalence of tuberculosis infection. Sarcoidosis Vasc. Diffuse Lung Dis., 2011, 28, 95-101.

[10] Bhat, P., Cervantes-Castañeda, R. A., Doctor, P. P., et al.: Mycophenolate mofetil therapy for sarcoidosis-associated uveitis. Ocul. Immunol. Inflamm., 2009, 17, 185-190.

[11] Baughman, R. P., Lower, E. E., Ingledue, R., et al.: Management of ocular sarcoidosis. Sarcoidosis Vasc. Diffuse Lung Dis., 2012, $29,26-33$.

[12] Miserocchi, E., Modorati, G., Di Matteo, F., et al.: Visual outcome in ocular sarcoidosis: retrospective evaluation of risk factors. Eur. J. Ophthalmol., 2011, 21, 802-810.

(Szepessy Zsuzsanna dr., Budapest, Mária u. 39., 1085 e-mail: szepzsu@yahoo.com)

Az Orvosi Hetilap 2013, 154, 1608. oldalán (40. szám) megjelent OH-Kvízre négy helyes megfejtés érkezett.

A beküldők: Dr. Bíró László (Budapest), Dr. Janik Leonárd (Budapest), Dr. Pallos Ágnes (Budapest) és Dr. Somogyi Erzsébet (Miskolc).

A nyerteseknek szívből gratulálunk.

A nyereményüket - egy, az Akadémiai Kiadó webáruházában kedvezményes vásárlásra jogosító kupont e-mailen küldjük el. 